\title{
Impact of ENSO regimes on developing- and decaying-phase precipitation during rainy season in China
}

\author{
Qing Cao ${ }^{1}$, Zhenchun Hao ${ }^{1,2}$, Feifei Yuan ${ }^{1}$, Zhenkuan $\mathrm{Su}^{1}$, Ronny Berndtsson ${ }^{3}$, Jie $\mathrm{Hao}^{4}$, and Tsring Nyima ${ }^{5}$ \\ ${ }^{1}$ State Key Laboratory of Hydrology Water Resources and Hydraulic Engineering, Hohai University, Nanjing, 210098, China \\ ${ }^{2}$ National Cooperative Innovation Center for Water Safety \& Hydro-Science, Hohai University, Nanjing, 210098, China \\ ${ }^{3}$ Department of Water Resources Engineering and Center for Middle Eastern Studies, Lund University, P.O. Box 118, \\ Lund, 22100, Sweden \\ ${ }^{4}$ Nanjing Hydraulic Research Institute, Nanjing, 210098, China \\ ${ }^{5}$ Investigation Bureau of Hydrology and Water Resources, Ali, Tibet Autonomous Region, 859000, China
}

Correspondence to: Zhenchun Hao (zhenchunhao@163.com) and Feifei Yuan (ffei.yuan@gmail.com)

Received: 6 March 2017 - Discussion started: 4 April 2017

Revised: 20 September 2017 - Accepted: 25 September 2017 - Published: 6 November 2017

\begin{abstract}
This study investigated the influence of five El Niño-Southern Oscillation (ENSO) types on rainy-season precipitation in China: central Pacific warming (CPW), eastern Pacific cooling (EPC), eastern Pacific warming (EPW), conventional ENSO and ENSO Modoki. The multi-scale moving $t$ test was applied to determine the onset and withdrawal of rainy season. Results showed that the precipitation anomaly can reach up to $30 \%$ above average precipitation during decaying CPW and EPW phases. Developing EPW could cause decreasing precipitation over large areas in China with 10-30\% lower than average precipitation in most areas. Conventional El Niño in the developing phase had the largest influence on ENSO-related precipitation among developing ENSO and ENSO Modoki regimes. Decaying ENSO also showed a larger effect on precipitation anomalies, compared to decaying ENSO Modoki. The difference between rainy-season precipitation under various ENSO regimes may be attributed to the combined influence of anti-cyclone in the western North Pacific and the Indian monsoon. Stronger monsoon and anti-cyclone are associated with enhanced rainy-season precipitation. The results suggest a certain predictability of rainy-season precipitation related to ENSO regimes.
\end{abstract}

\section{Introduction}

El Niño-Southern Oscillation (ENSO) is one of the most important factors affecting precipitation, which has been achieved urgent attention worldwide (Li et al., 2016; Wang et al., 2006; Preethi et al., 2015; Yuan et al., 2016a, b; Zaroug et al., 2014; Brigode et al., 2013). Many researchers have studied various aspects of precipitation, such as seasonal precipitation and extreme precipitation (Jiang et al., 2016, 2013). Rainy season characteristics (e.g., onset, withdrawal and precipitation of rainy season), however, are less considered, which are of immense significance to rain-fed agriculture in many countries like China. Reliable prediction of onset and withdrawal of rainy season will assist on-time preparation of farmlands and is significant to ecosystems (Omotosho et al., 2000; Marteau et al., 2011). In addition, rainy season is a period when it is easier for flooding, and rainy-season precipitation could provide certain predictability of flood occurrence. China is an ENSO-sensitive country and prone to flood and drought occurrence (Q. Zhang et al., 2016; W. Zhang et al., 2014; Feng et al., 2011, 2010; Wang and Wang, 2013; Feng and Li, 2011). Thus, it is significant to investigate rainyseason precipitation under ENSO regimes. Cai (2003) observed similar inter-decadal oscillation and abrupt variations between rainfall of rainy season in Fujian and Niño 3 SST. Lu (2005) pointed out that rainfall in the rainy season in northern China is related to sea surface temperature anomalies (SSTA) in the equatorial eastern Pacific and negative (positive) SSTA could trigger heavier (lighter) rainy-season pre- 
cipitation. However, such studies mainly concentrated on regional scales and single ENSO mode, rather than on continental scale and various ENSO regimes, which is important for overall understanding of relationship between ENSO and Chinese rainy-season precipitation. In order to decipher this, it is necessary to explore the spatial pattern of precipitation during the rainy season under various ENSO regimes at the continental scale in China.

Different types of ENSO regimes have been demonstrated based on the Pacific spatial pattern SSTA (Kao and Yu, 2009; Larkin and Harrison, 2005; Ashok et al., 2007; Trenberth, 1997; Tedeschi et al., 2013; Kim et al., 2009). Conventional ENSO episodes, including El Niño (EN) and La Niña (LN), are defined based on SST anomalies in the Niño 3.4 region, and El Niño is mainly characterized by eastern Pacific warming in the cold tongue of the eastern Pacific Ocean (Kim et al., 2009). Several researchers have identified different episodes of SST in the Pacific, such as the central Pacific warming and eastern Pacific cooling (Larkin and Harrison, 2005; Weng et al., 2007; Kao and Yu, 2009). Kim et al. (2009) divided ENSO into three types, i.e., central Pacific warming (CPW), eastern Pacific cooling (EPC) and eastern Pacific warming (EPW). The division of ENSO is also based on SSTA in Niño 3, Niño 3.4 and Niño 4 regions. Ashok et al. (2007) introduced a new type of ENSO event, ENSO Modoki, which is different from conventional ENSO. ENSO Modoki is characterized by positive SSTA in the central Pacific, bounded by negative SSTA in the western and eastern Pacific.

ENSO and ENSO Modoki have different influences on precipitation (Ashok et al., 2007, 2009; Weng et al., 2007; Taschetto and England, 2009). Q. Zhang et al. (2016) pointed out that CPW, EPC and EPW regimes showed various performance on seasonal precipitation over the Huaihe River basin. Precipitation below average usually occurs in southern China in ENSO Modoki years, whereas the conventional ENSO tends to imply precipitation above average (W. Zhang et al., 2014). In contrast, enhanced precipitation over the Huaihe River basin often occurs during decaying El Niño Modoki events in summer, whilst reduced precipitation signals are found in the corresponding season in the decaying year of El Niño (Feng et al., 2011). It can be seen that the influence of ENSO regimes on precipitation varies among locations in China. The National Climate Center (NCC) succeeded in predicting the severe flood over the Yangtze River basin in the typical El Niño year of 1997-1998. Nonetheless, NCC failed to predict the enhanced precipitation in the Huaihe River basin in 2002-2003, since it was an El Niño Modoki year rather than a conventional El Niño. This highlights the significance of correct distinguishing between ENSO and ENSO Modoki.

Different performance of precipitation under various ENSO regimes is associated with atmospheric circulation and monsoon (Tedeschi et al., 2013; Feng et al., 2010; Cai et al., 2010; Black et al., 2003; Chang et al., 2001; R. Zhang et al., 2014; Onyutha and Willems, 2015). Wu et al. (2003) explained the physical mechanism of links between precipitation and SSTs through features of atmospheric circulation. Wang et al. (2004) pointed out that the local onset of rainy season in the South China Sea is related to mean summer monsoon onset. Cai et al. (2010) argued that a rainfall reduction in South East Queensland in Australia is related to an eastward shift in the Walker circulation. Feng et al. (2011) pointed out that China rainfall anomalies were mainly due to anomalous anti-cyclonic flow in the western North Pacific associated with El Niño Modoki and El Niño events. Gerlitz et al. (2016) argued that ENSO-induced precipitation variability in tropical regions is directly associated with the atmospheric circulation. The atmospheric circulation and monsoon have different influences on two types of ENSO (Feng and Li, 2013; Zhang et al., 2011; Zhou and Chan, 2007). As a consequence, the investigation of atmospheric circulation and monsoon is used to explain different performance of rainy-season precipitation anomalies under various ENSO regimes in this study.

850 mbar wind variability is associated with SSTA in the equatorial Pacific and precipitation anomalies in China (Zhang et al., 1999; Zhou and Chan, 2007; Wang et al., 2004; W. Zhang et al., 2016). Fan et al. (2013) pointed out that 850 mbar vector winds are related to the moisture transportation from western tropical Pacific to the subtropical region, which determines the precipitation over the Yangtze-Huai river valley region. Huang et al. (2004) and R. Zhang et al. (2014) presented the atmospheric circulation and monsoon variability by the composite distribution of wind anomalies at 850 mbar in different phases of El Niño and La Niña to explain precipitation variation in China. Feng et al. (2011) compared the difference of 850 mbar wind anomalies in decaying ENSO and ENSO Modoki phases to explain the physical mechanism of seasonal precipitation variation in China. Hence, 850 mbar vector winds reflecting atmospheric circulation and monsoon variability are used to explore the underlying causes of precipitation anomalies in this study.

The influence of ENSO and ENSO Modoki regimes on Chinese precipitation has been studied intensively. However, research has been limited to the comparison of impacts of developing (decaying) ENSO and ENSO Modoki on precipitation at the regional scale in China. Therefore, this study aims to improve our understanding of ENSO-induced precipitation during rainy season and to explore the effect of five important ENSO types (i.e., CPW, EPC, EPW, ENSO and ENSO Modoki) in the developing and decaying phase on the continental-scale precipitation. The multi-scale moving $t$ test method was applied to determine the onset and withdrawal of the rainy season. The underlying causes of the spatial patterns of rainy-season precipitation were analyzed by the variability of atmospheric circulation in the western North Pacific (WNP) together with monsoon. 


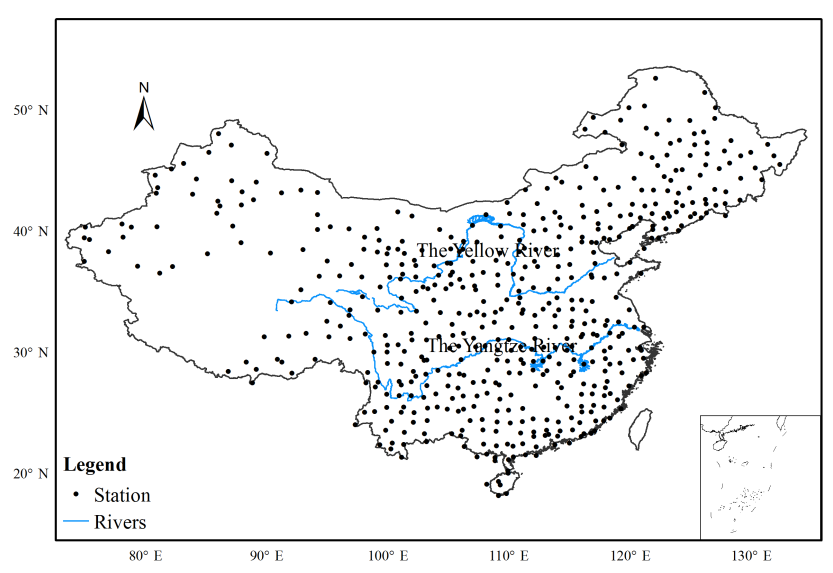

Figure 1. The spatial distribution of precipitation stations used in this study.

\section{Study area and data}

China, located in middle latitude in eastern Asia $\left(18-54^{\circ} \mathrm{N}\right.$, $\left.73-135^{\circ} \mathrm{E}\right)$, is the most populous country in the world (Fig. 1), with a population of over 1.381 billion and an area of approximately 9.6 million $\mathrm{km}^{2}$. China is mainly dominated by monsoon climate and mountain plateau climate, which lead to pronounced rainfall differences among different seasons and regions.

Daily precipitation data from 1960 to 2015 at 536 observation stations in China were selected for this study (Ren et al., 2012). The data were obtained from China Meteorological Data Sharing Service System, and the data quality has been regularly checked. The locations of the observation stations are shown in Fig. 1. The stations are distributed unevenly, with fewer stations in the northwestern part of China. Hence, we applied Kriging interpolation to induce a resolution of $0.2^{\circ} \times 0.2^{\circ}$.

The dataset of National Oceanic and Atmospheric Administration (NOAA) extended reconstructed SST was used to identify different types of conventional ENSO (Huang et al., 2015). ENSO Modoki index (EMI) was obtained from the Japan Agency for Marine Science and Technology. In addition, the National Centers for Environmental Prediction (NCEP)/National Centers for Atmospheric Research (NCAR) reanalysis data were used to investigate underlying causes of the spatial pattern of precipitation under different ENSO regimes (Kalnay et al., 1996).

\section{Methodology}

\subsection{Determination of rainy season}

The onset and withdrawal of rainy season was determined by the multi-scale moving $t$ test method. This method is characterized by the detection of mutation points between two subsamples with equal size $n$, where $n$ is the length of the subsample $(n=30,31, \ldots, 182 / 183 ; 182 / 183$ corresponds to half the value of length of 1 year 365/366). Theoretically, the length of subsamples in this study ranged between 1 and $182 / 183$. However, as the onset or withdrawal of the rainy season, it will not be considered if the length of the subsample is one day or just several days when the abruption point is prominent. As a result, the length of the subsample is limited between 30 and 182/183. The determination of the mutation point can be described as (Fraedrich et al., 1997)

$t(n, i)=\left(\bar{x}_{i 2}-\bar{x}_{i 1}\right) n^{1 / 2}\left(s_{i 2}^{2}+s_{i 1}^{2}\right)^{-1 / 2}$,

where $\bar{x}_{i 1}$ and $\bar{x}_{i 2}$ defined as

$\bar{x}_{i 1}=\sum_{j=i-n}^{i-1} \frac{x_{j}}{n} ; s_{i 1}^{2}=\sum_{j=i-n}^{i-1}\left(x_{j}-\bar{x}_{i 1}\right)^{2} /(n-1)$,
$\bar{x}_{i 2}=\sum_{j=i}^{i+n-1} \frac{x_{j}}{n} ; s_{i 2}^{2}=\sum_{j=i}^{i+n-1}\left(x_{j}-\bar{x}_{i 2}\right)^{2} /(n-1)$,

and $x_{i}$ is daily precipitation for Julian day $i$ within 1 year and for one station. $\bar{x}_{i 1}$ and $\bar{x}_{i 2}$ are the mean values of the subsamples before and after the Julian day $i$, respectively.

The $t$ value calculated above was normalized by the 0.01 test value shown in Eq. (4), which is equal to the result of Mann-Kendall test at 0.05 significance level.

$t_{\mathrm{r}}(n, i)=t(n i) / t_{0.01}(n)$,

where $t_{\mathrm{r}}(n, i)$ can be taken as the threshold to detect mutations. $t_{\mathrm{r}}(n, i)>1.0$ represents an increasing trend while $t_{\mathrm{r}}(n, i)<1.0$ is a decreasing trend. The onset of rainy season in this study was defined as the mutation point corresponding to a maximum $t_{\mathrm{r}}(n, i)$ value. For this case, precipitation changes from a smaller to a higher value. Likewise, the withdrawal is defined as the changing point corresponding to a minimum $t_{\mathrm{r}}(n, i)$ value.

\subsection{Classification of ENSO and ENSO Modoki regimes}

Three types of ENSO were classified based on the definition proposed by Kim et al. (2009). The years dominated by CPW, EPC and EPW are listed in Table 1.

The definition of ENSO Modoki and conventional ENSO was demonstrated. Specifically, warm (cold) episodes of ENSO Modoki, abbreviated as MEN (MLN), were defined as EMI above (below) $0.7 \mathrm{SD}(-0.7 \mathrm{SD})$, where $\mathrm{SD}$ is the standard deviation (Ashok et al., 2007). EMI $=[$ SSTA $]$ A $0.5 \times[$ SSTA $] \mathrm{B}-0.5 \times[\mathrm{SSTA}] \mathrm{C}$, where [SSTA $] \mathrm{A}$, [SSTA $] \mathrm{B}$, [SSTA]C represents the SSTA in region A $\left(10^{\circ} \mathrm{S}-10^{\circ} \mathrm{N}\right.$, $\left.165^{\circ} \mathrm{E}-140^{\circ} \mathrm{W}\right)$, region $\mathrm{B}\left(15^{\circ} \mathrm{S}-5^{\circ} \mathrm{N}, 110^{\circ} \mathrm{W}-70^{\circ} \mathrm{W}\right)$ and region $\mathrm{C}\left(10^{\circ} \mathrm{S}-20^{\circ} \mathrm{N}, 125^{\circ} \mathrm{E}-145^{\circ} \mathrm{E}\right)$, respectively. Likewise, the conventional EN (LN), abbreviated as CEN (CLN), was defined as SSTA above (below) $0.7 \mathrm{SD}(-0.7 \mathrm{SD})$ in the area of $5^{\circ} \mathrm{N}-5^{\circ} \mathrm{S}, 90^{\circ} \mathrm{W}-140^{\circ} \mathrm{W}$ (Tedeschi et al., 2013). 
Table 1. Years dominated by CPW, EPC and EPW regimes during 1960-2015.

\begin{tabular}{lll}
\hline EPW & EPC & CPW \\
\hline $1965,1972,1976,1982,1987,1997,2015$ & $\begin{array}{l}1964,1970,1973,1975,1988,1998, \\
1999,2007,2010,2011\end{array}$ & $1963,1969,1991,1994,2002,2004,2009$ \\
& & \\
\hline
\end{tabular}
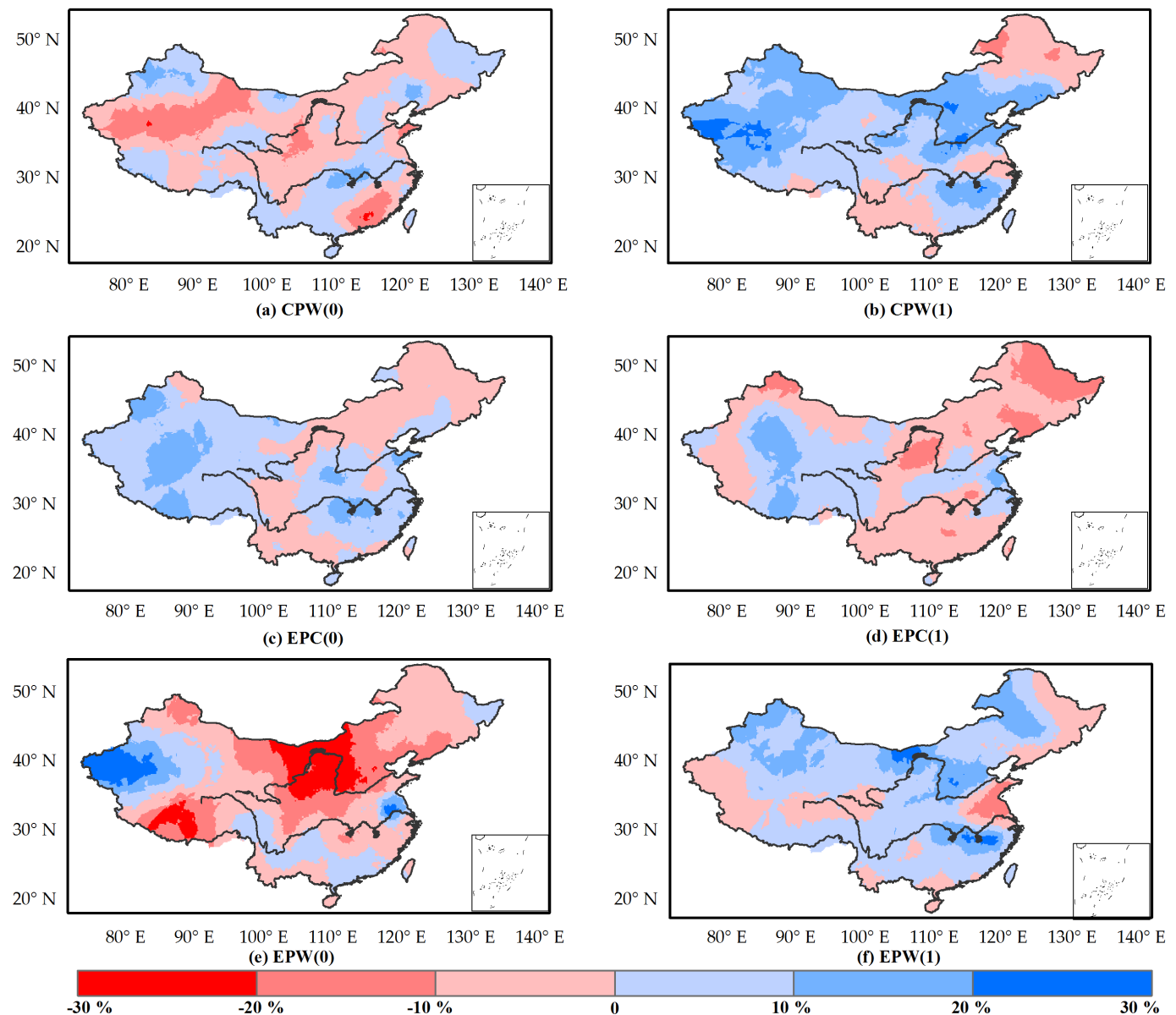

Figure 2. Spatial pattern for rainy-season precipitation anomaly (PARS) during the CPW (first row), EPC (second row) and EPW (third row) episodes in the phase of ENSO developing year (0) and decaying year (1). The sign " 0 " in the parentheses denotes ENSO developing year and " 1 " denotes decaying year.

This definition gives an opportunity to judge the ENSO type of the rainy season rather than the whole year, which is greater than definition proposed by Trenberth (1997).

\subsection{Precipitation anomaly index during rainy season (PARS)}

Precipitation anomaly can present the difference of precipitation between ENSO years and normal years and demonstrate the influence of ENSO regimes on precipitation more directly. Q. Zhang et al. (2013) used precipitation anomaly index to explore the effect of ENSO on precipitation in the East River basin, southern China. Q. Zhang et al. (2016) in- vestigated the influence of ENSO and ENSO Modoki on seasonal precipitation over the Huaihe River basin by using precipitation anomaly index. Precipitation anomaly index is defined as

$\operatorname{PARS}_{i j}=\left(\frac{\operatorname{PRS}_{i j}}{\operatorname{PRS}_{i j}}-1\right) \times 100 \%$,

where PARS $_{i j}$ denotes precipitation anomaly during rainy season at $i$ th station in $j$ th year; $\mathrm{PRS}_{i j}$ denotes mean daily precipitation during rainy season at $i$ th station in $j$ th year, and $\mathrm{PR} \overline{\mathrm{S}} \mathrm{N}_{i j}$ denotes mean daily precipitation during rainy season at $i$ th station in $j$ th normal year. The normal year refers to a year without ENSO event occurring. 

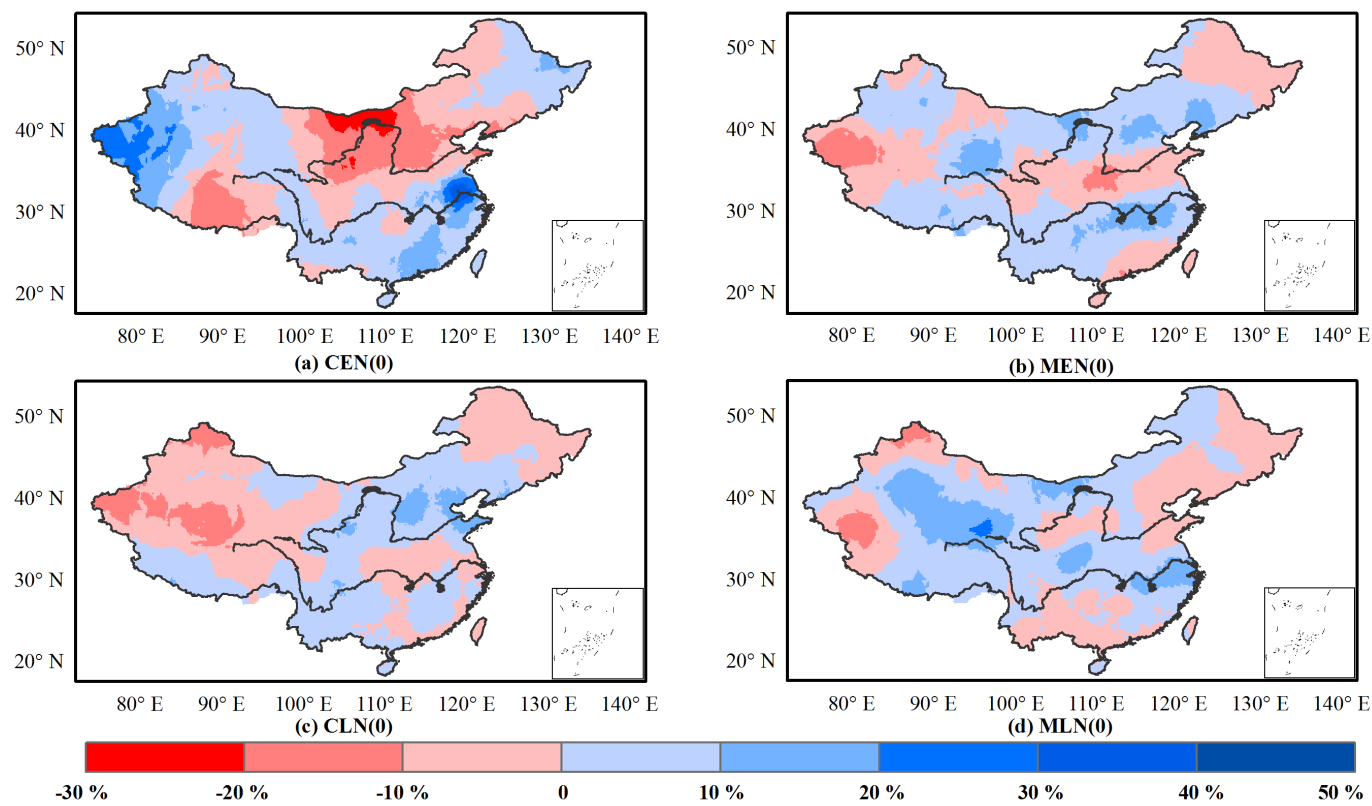

Figure 3. Spatial pattern of precipitation anomalies during rainy season (PARS) during developing (0) conventional ENSO and ENSO Modoki events.

\section{Results and discussion}

\subsection{Precipitation anomaly during rainy season (PARS) influenced by CPW, EPC and EPW regimes}

The spatial variability of PARS under CPW, EPC and EPW regimes in the phase of developing and decaying years is presented in Fig. 2. The distribution of precipitation anomaly is irregular over the whole area in the developing phase of CPW. The coastal regions in southeastern China that had the largest amount of rainy-season precipitation presented the largest decreasing trend, with the precipitation anomaly reaching $30 \%$ below average precipitation. The upper and middle reaches of the Yangtze River and the Yellow River showed decreasing precipitation, whereas the lower reaches had the opposite trend. The decaying CPW regime had a relatively regular spatial pattern. More specifically, most parts of China presented increasing precipitation during rainy season, with the largest PARS being $20 \%$ above average precipitation. The distribution of PARS influenced by the decaying CPW is similar to that by the developing EPC, with shrinking extent of enhanced precipitation in central China for developing EPC. The distribution of PARS is similar as well in the two phases of EPC (Fig. 2, second row), with precipitation above average in northwestern China and precipitation below average in northeastern China. The difference between the two phases lies in the increasing (decreasing) precipitation in southeastern China in the developing (decaying) phase. Nonetheless, developing and decaying EPW (Fig. 2, third row) showed opposite spatial precipitation pat- tern. Most parts of China presented dry signals in the phase of developing EPW, which became stronger northwards, and more than $30 \%$ below average precipitation can be identified in northern China. However, there is above average precipitation in most regions of China in the case of decaying EPW, with PARS values ranging between 0 and $30 \%$. In summary, the CPW decaying phase (EPC developing phase) deserves more attention than the developing (decaying) phase, since it shows more prominent wet signals. Both phases are significant for the EPW regimes, due to the obvious dry (wet) signals shown in the developing (decaying) phase.

\subsection{Precipitation anomaly during rainy season (PARS) impacted by ENSO and ENSO Modoki regime}

Figures 3 and 4 present precipitation anomalies during rainy season (PARS) for warm and cold episodes of conventional ENSO and ENSO Modoki in a developing phase and a decaying phase, respectively. Precipitation increased in a band stretching from northwestern China to the coastal region in the southeast, with the largest precipitation anomaly (40\%) occurring in southeastern China under a developing CEN regime (Fig. 3a). The dry condition is more severe northwards in central China, with PARS equal to about $-30 \%$ in the northern parts of central China. W. Zhang et al. (2016) concluded that strong El Niño events are associated with summer monsoon flooding over the Yangtze River, which is consistent with our results. The distribution of rainy-season precipitation for developing El Niño is also in agreement with the research by Zhang et al. (2011). Northern China had 

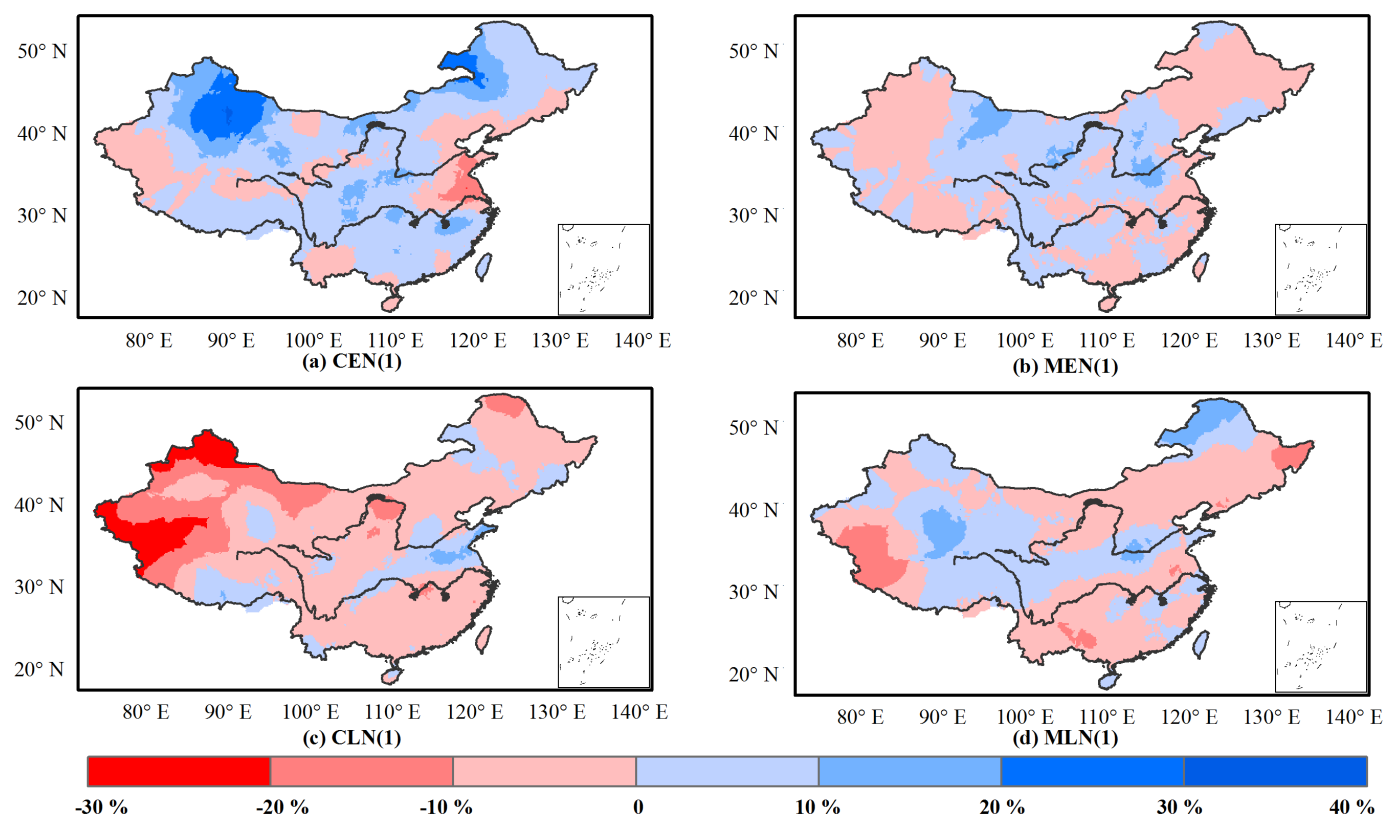

Figure 4. Spatial pattern of precipitation anomalies during rainy season (PARS) for decaying (1) conventional ENSO and ENSO Modoki events.

an opposite PARS pattern for developing El Niño Modoki, in comparison to developing CEN (Fig. 3b). Nonetheless, the two phases showed similar precipitation distribution, with reduced precipitation in central China (approximately -10\%) and enhanced precipitation in southern China. Typically, developing CEN demonstrated more obvious wet or dry signals compared to MEN. Moreover, the wet and dry condition for developing CEN is the most serious among all ENSO and ENSO Modoki regimes in both developing and decaying phases, with the largest precipitation anomaly reaching $50 \%$ above average precipitation amount and lowest $30 \%$ below. This means that developing CEN should be paid urgent attention to for flooding and drought monitoring. The spatial pattern of PARS for developing CLN presented similar signals with developing MEN, with a shorter wet precipitation band in northern China for developing CLN (Fig. 3c). The increased precipitation was shifted westwards for the developing MLN, compared to cold episodes of conventional ENSO (Fig. 3d). ENSO and ENSO Modoki regimes in the developing phase presented various distribution of precipitation anomalies. Wet or dry signals are more easily shown for the warm episodes of conventional ENSO, in comparison to the other three regimes. Similar patterns of PARS for developing CLN and MEN should be further studied.

Decaying ENSO and ENSO Modoki years showed different features of PARS (Fig. 4). Most parts of China presented increasing precipitation for decaying CEN, with more than $30 \%$ above average precipitation identified in northern China (Fig. 4a). The decaying phase of MEN (Fig. 4b) presented shrinking extent of enhanced precipitation, which was con- densed in the central parts of China, ranging between 0 and $10 \%$. The result is consistent with conclusions from Feng et al. (2011), who found obvious rainfall anomalies in southern China for decaying El Niño and no prominent rainfall variations in the corresponding phase of El Niño Modoki. In terms of the cold episodes of ENSO (Fig. 4c), approximately $95 \%$ of China showed dry signals, and the condition was more serious eastwards, being $30 \%$ below average precipitation amount. We can see that the spatial pattern of PARS for the decaying CLN is opposite to that of CEN. Decaying MLN (Fig. 4d) showed a larger extent of enhanced precipitation in a band stretching from western China to parts of the Yellow River basin, in comparison to CLN. In conclusion, the decaying phases of conventional ENSO showed more obvious wet or dry signals compared to ENSO Modoki, with most parts of China displaying increasing (decreasing) precipitation for the CEN (CLN).

This study analyzed spatial patterns of precipitation under different ENSO regimes, since ENSO is the leading driver of precipitation anomaly in China (Xiao et al., 2015). Xu et al. (2016) revealed that increasing autumn precipitation in southern China is due to the combined ENSO and Indian Ocean Dipole (IOD) events. Other researchers also concluded that IOD and ENSO have mutual impact on precipitation anomalies in China (Weng et al., 2011; Liu et al., 2009; Wu et al., 2012). Moreover, Pacific Decadal Oscillation, subtropical high, also influences the distribution of Chinese precipitation (Chan, 2005; Wang et al., 2008; Chang et al., 2000; Niu and Li, 2008; Ouyang et al., 2014). As a result, the spatial patterns of PARS under ENSO regimes may 

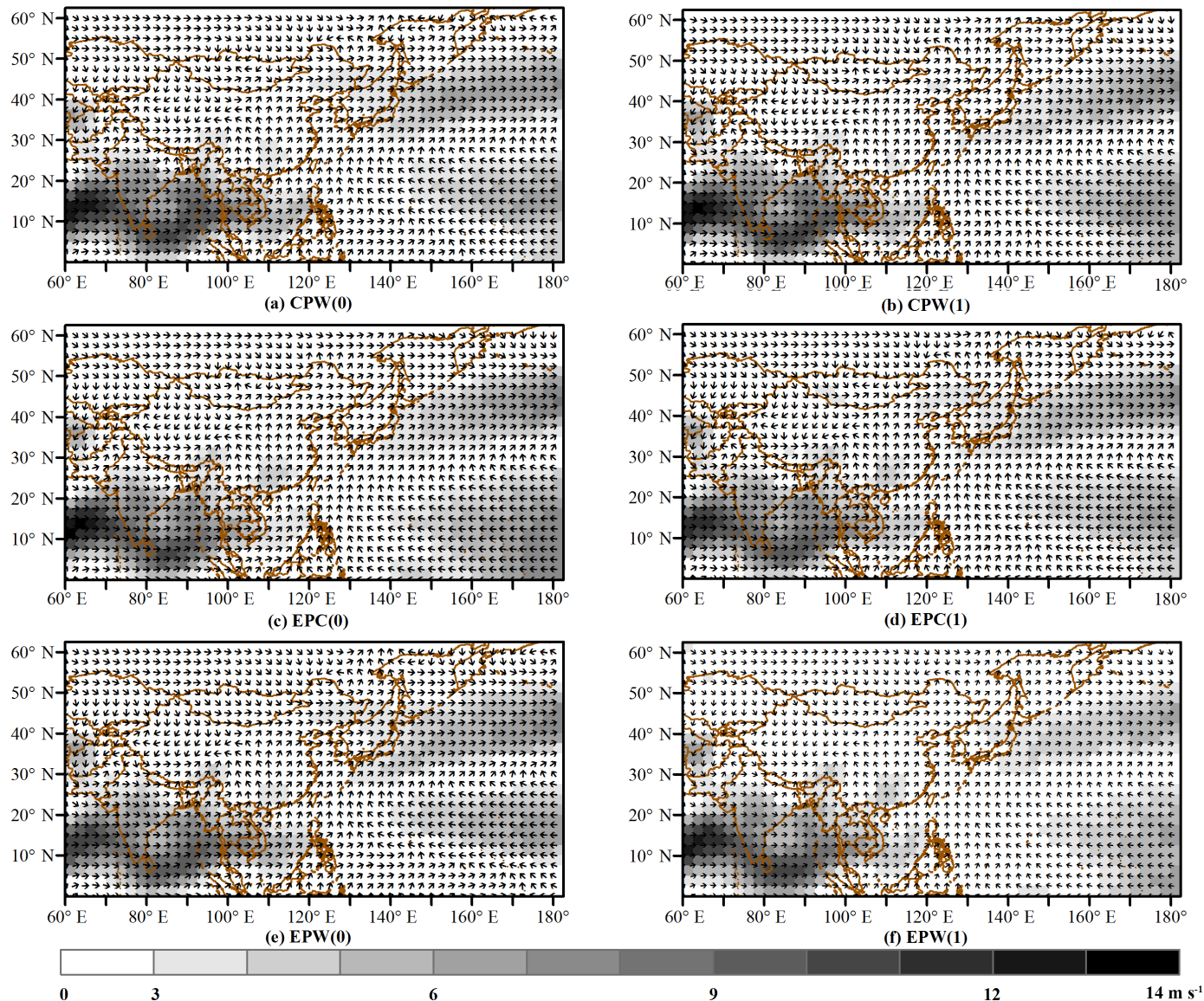

Figure 5. Composites of 850 mbar vector wind for mainland China during CPW, EPC and EPW developing (0) and decaying (1) phases. Arrows show the direction of wind $\left(\mathrm{ms}^{-1}\right)$; grey shaded areas denote wind speed above $3 \mathrm{~m} \mathrm{~s}^{-1}$.

be determined not only by ENSO but also by the combination of various drivers, which ought to be studied further.

\subsection{Composites of circulation}

Figure 5 presents the composites of $850 \mathrm{mbar}$ vector wind for three types of ENSO. There is a strengthening of westerly and southwesterly wind in the decaying year of CPW (Fig. 5b), which brings more moisture to China, compared to developing CPW (Fig. 5a). This may explain the enhanced precipitation in decaying CPW (Fig. 2b). The difference between developing and decaying EPC (Fig. 5c-d) lies in the shift of anti-cyclonic flow in the western part of North Pacific (WNP). The eastward anti-cyclone for the decaying EPC weakened the transportation of moisture in eastern China and caused reduced precipitation (Fig. 2d). The decaying EPW (Fig. 5f) experienced stronger western and southwestern wind but weakened anti-cyclone compared to the developing phase (Fig. 5e). The WNP anti-cyclone could bring plentiful moisture to China, so weakened anti-cyclonic flow will cause reduced precipitation (Feng et al., 2011). However, most parts of China presented wetter signals in the phase of decaying EPW in comparison to developing EPW. Therefore, it can be pointed out that the India monsoon plays a more significant role in the formation of rainy-season precipitation during EPW phases compared to the atmospheric circulation.

Figure 6 shows the underlying causes of different performance of conventional ENSO and ENSO Modoki in the developing phase by analysis of the $850 \mathrm{hp}$ wind. Compared to developing CEN, developing MEN experienced reduced precipitation in western China and generally enhanced precipitation in eastern parts under the combined influence of stronger monsoon and weakened anti-cyclone (Fig. 6ab). Stronger anti-cyclonic flow in the phase of developing La Niña Modoki (Fig. 6d) may cause the enhanced precipitation in western parts of China compared to conventional La Niña regime in developing years (Fig. 6c).

The wind composites of warm and cold episodes of decaying ENSO and ENSO Modoki are presented in Fig. 7. Compared to decaying CEN, the wet signal of precipitation is weaker in the decaying year of MEN, which may be attributed to the weakened anti-cyclonic flow in WNP and western winds for the decaying MEN. The difference of 

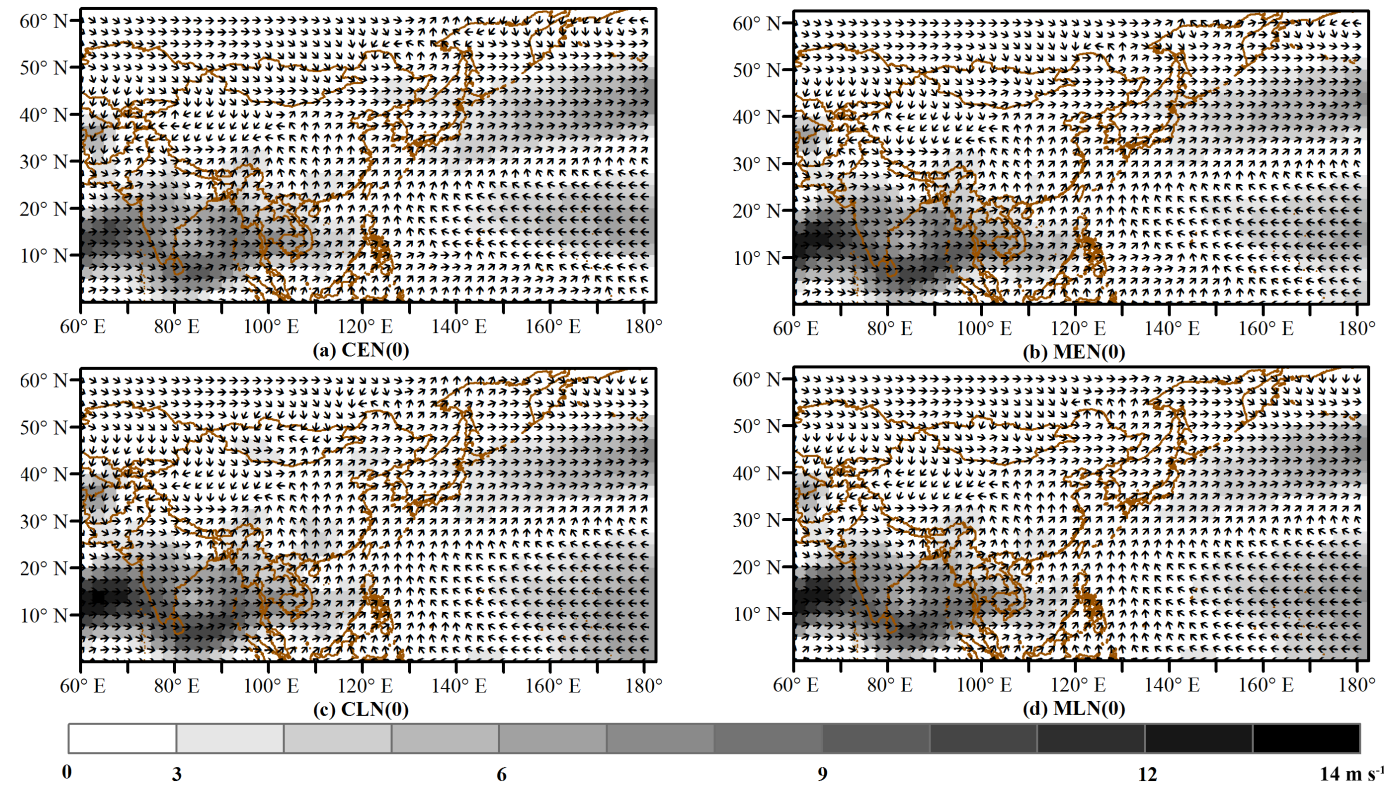

Figure 6. Composites of 850 mbar vector wind for mainland China during ENSO and ENSO Modoki developing (0) phases. Arrows show the direction of wind $\left(\mathrm{ms}^{-1}\right)$; grey shaded areas denote wind speed above $3 \mathrm{~ms}^{-1}$.
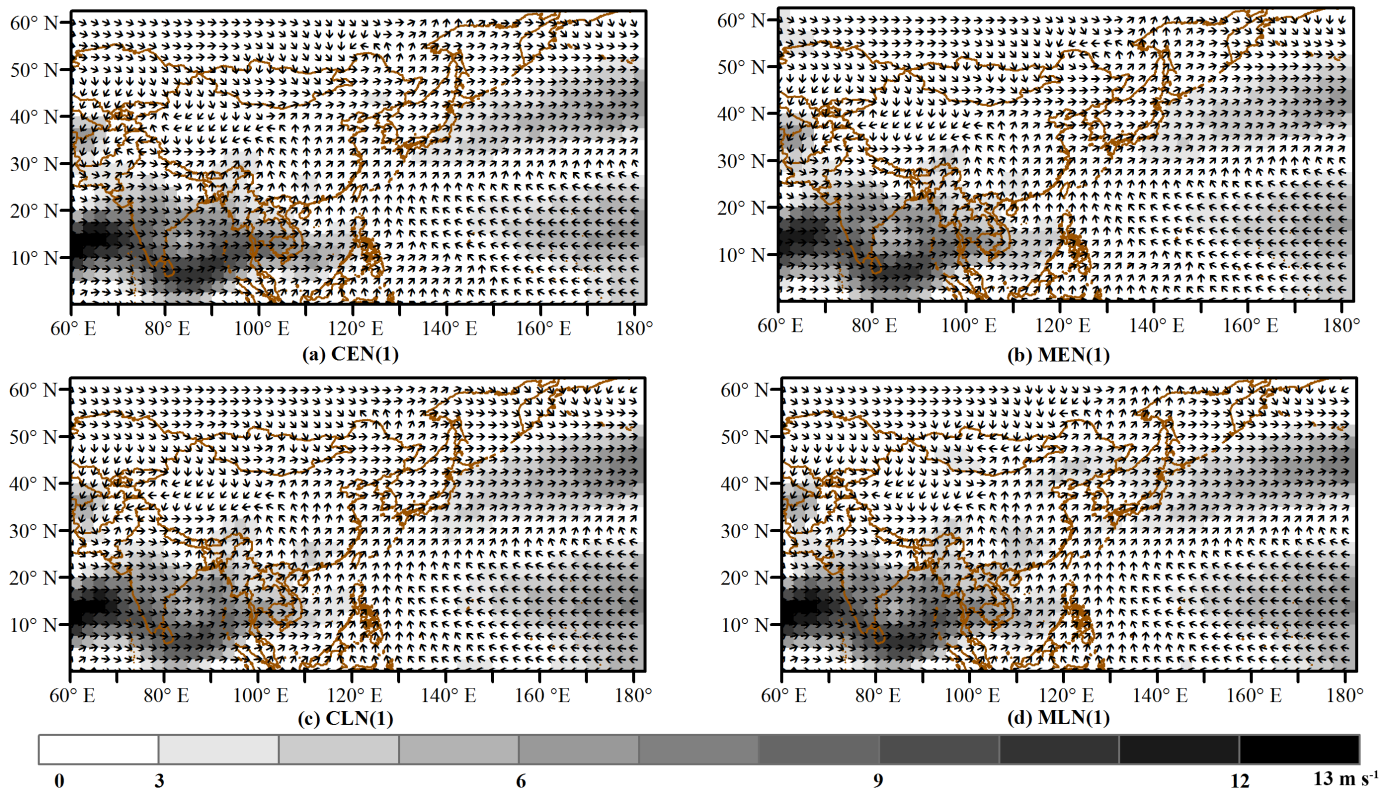

Figure 7. Composites of 850 mbar vector wind for mainland China during ENSO and ENSO Modoki decaying (1) phases. Arrows show the direction of wind $\left(\mathrm{ms}^{-1}\right)$; grey shaded areas denote wind speed above $3 \mathrm{~m} \mathrm{~s}^{-1}$

wind composites between decaying CLN and MLN indicates similar configuration, with stronger westerly wind and anticyclone causing enhanced precipitation for decaying MLN.

In summary, westerly winds seem to play more significant role in the phase of CPW and EPW, while developing La Niña and La Niña Modoki are dominated by the anticyclone. The spatial pattern of PARS is the reflection of com- bined influence of westerly winds and anti-cyclonic flow for the EPC and decaying ENSO and ENSO Modoki regimes.

It can be seen that the spatial pattern of precipitation during the rainy season in China is dominated by westerly winds from India and anti-cyclone in WNP, which is equivalent to the results by Dai and Wigley (2000), Feng and Li (2011), and Wu et al. (2003). Generally, stronger western and south- 
western winds are related to increasing precipitation. It is in agreement with the research of Zhang et al. (1996) and Wang et al. (2000), who pointed out that southeastern and southwestern winds could substantially enhance the moisture transportation to China. Wu et al. (2003) also found that East Asian monsoon is positively related to precipitation variations, which is consistent with our result. Likewise, the westward and stronger anti-cyclone is related to enhanced PARS. Wu et al. (2003) reported that the anomalous low-level anti-cyclone is determined by large-scale equatorial heating anomalies and local air-sea interactions. Westerlies and anti-cyclone are of dominant importance for the ENSO-induced precipitation during the rainy season. However, cyclonic flow may have larger influence on Chinese precipitation under certain circumstances. For example, the autumn drought in southwest China in 2009 was determined by a strong cyclone in WNP for ENSO Modoki (W. Zhang et al., 2013b). Feng et al. (2011) also revealed that the WNP circulation is cyclonic in winter and then becomes weak in the following spring and anti-cyclonic flow in summer for El Niño Modoki. As a consequence, WNP anti-cyclone has a larger effect on East Asian precipitation on the inter-annual or inter-decadal scale, but anti-cyclone and cyclone are both crucial for the determination of precipitation on the annual or smaller scale.

\section{Conclusion}

This study investigated the distribution of PARS under various ENSO types in developing and decaying phases and their underlying causes. It was found that northwestern, central and southeastern China experience increasing precipitation for decaying $\mathrm{CPW}$ and $\mathrm{EPW}$, and positive precipitation anomaly ranges from 0 to $30 \%$ due to the stronger westerly and southwesterly winds. The developing phase of EPW presents overall negative rainy-season precipitation anomalies in China with more than $30 \%$ below average precipitation identified in many parts of the country, which is a result of weak westerly winds. The different spatial distribution of rainy-season precipitation under developing and decaying ENSO and ENSO Modoki regimes was also examined. Conventional El Niño in developing years showed larger influence on precipitation during rainy season in China as compared to developing CLN, MEN and MLN. Conventional ENSO in the decaying phase is more likely to show wet and dry signals in comparison to the corresponding ENSO Modoki regimes. Different performance of conventional ENSO and ENSO Modoki is a reflection of combined influence of the India monsoon and the WNP anti-cyclone. This study improved our understanding on the spatial variability of ENSO-induced precipitation during rainy season in China and the underlying causes. These results suggest that improved predictability can be achieved for rainy-season precipitation related to ENSO regimes. We suggest that fur- ther work should focus on the influence of interactive ENSO and other drivers on precipitation to evaluate and improve the predictive ability.

Data availability. The daily precipitation, NOAA extended reconstructed SST, ENSO Modoki index (EMI) and the NCEP-NCAR reanalysis datasets used in this study are available for download under the following URLs:

- daily precipitation: http://data.cma.cn/data/detail/dataCode/ SURF_CLI_CHN_MUL_DAY_V3.0.html (Ren et al., 2012)

- NOAA extended reconstructed SST: https://data.nodc.noaa. gov/cgi-bin/iso?id=gov.noaa.ncdc:C00884 (Huang et al., 2015)

- EMI: http://www.jamstec.go.jp/frsgc/research/d1/iod/DATA/ emi.monthly.txt (Japan Agency for Marine Science and Technology, 2017)

- NCEP/NCAR reanalysis data: https://www.esrl.noaa.gov/psd/ data/gridded/data.ncep.reanalysis.html (Kalnay et al., 1996)

Author contributions. QC, ZH and FY conceived the study. All authors contributed to writing the paper.

Competing interests. The authors declare that they have no conflict of interest.

Acknowledgements. Funding from the National Key Research Projects (grant no. 2016YFC0402704) and the National Natural Science Foundation of China (grant no. 41371047) are gratefully acknowledged. Support from the China Postdoctoral Science Foundation (grant no. 2016M601711) and the Jiangsu Planned Projects for Postdoctoral Research Funds (grant no. 1601027B) are appreciated.

Edited by: Luis Samaniego

Reviewed by: two anonymous referees

\section{References}

Ashok, K., Behera, S. K., Rao, S. A., Weng, H., and Yamagata, T.: El Niño Modoki and its possible teleconnection, J. Geophys. Res.-Oceans, 112, C11007, https://doi.org/10.1029/2006JC003798, 2007.

Ashok, K., Tam, C. Y., and Lee, W. J.: ENSO Modoki impact on the Southern Hemisphere storm track activity during extended austral winter, Geophys. Res. Lett., 36, L12705, https://doi.org/10.1029/2009g1038847, 2009.

Black, E., Slingo, J., and Sperber, K. R.: An observational study of the relationship between excessively strong short rains in coastal East Africa and Indian Ocean SST, Mon. Weather Rev., 131, 74-94, https://doi.org/10.1175/15200493(2003)131<0074:AOSOTR>2.0.CO;2, 2003. 
Brigode, P., Micovic, Z., Bernardara, P., Paquet, E., Garavaglia, F., Gailhard, J., and Ribstein, P.: Linking ENSO and heavy rainfall events over coastal British Columbia through a weather pattern classification, Hydrol. Earth Syst. Sci., 17, 1455-1473, https://doi.org/10.5194/hess-17-1455-2013, 2013.

Cai, W., Van Rensch, P., Cowan, T., and Sullivan, A.: Asymmetry in ENSO teleconnection with regional rainfall, its multidecadal variability, and impact, J. Climate, 23, 4944-4955, https://doi.org/10.1175/2010JCLI3501.1, 2010.

Cai, X.: Relationship between West Pacific subtropical high and ENSO and its influence on rainfall distribution of rainy season in Fujian, J. Trop. Meteorol., 9, 57-63, http://www.cqvip.com/ qk/85390x/2003001/8073469.html, 2003.

Chan, J. C. L.: PDO, ENSO and the early summer monsoon rainfall over south China, Geophys. Res. Lett., 32, L08810, https://doi.org/10.1029/2004GL022015, 2005.

Chang, C., Zhang, Y., and Li, T.: Interannual and interdecadal variations of the East Asian summer monsoon and tropical Pacific SSTs. Part I: Roles of the subtropical ridge, J. Climate, 13, 4310-4325, https://doi.org/10.1175/15200442(2000)013<4310:IAIVOT>2.0.CO;2, 2000.

Chang, C., Harr, P., and Ju, J.: Possible roles of Atlantic circulations on the weakening Indian monsoon rainfall-ENSO relationship, J. Climate, 14, 2376-2380, https://doi.org/10.1175/15200442(2001)014<2376:PROACO>2.0.CO;2, 2001.

Dai, A. and Wigley, T. M. L.: Global patterns of ENSOinduced precipitation, Geophys. Res. Lett., 27, 1283-1286, https://doi.org/10.1029/1999g1011140, 2000.

Fan, L., Shin, S.-I., Liu, Q., and Liu, Z.: Relative importance of tropical SST anomalies in forcing East Asian summer monsoon circulation, Geophys. Res. Lett., 40, 2471-2477, https://doi.org/10.1002/grl.50494, 2013.

Feng, J. and Li, J.: Influence of El Niño Modoki on spring rainfall over south China, J. Geophys. Res., 116, D13102, https://doi.org/10.1029/2010jd015160, 2011.

Feng, J. and Li, J.: Contrasting impacts of two types of ENSO on the boreal spring Hadley circulation, J. Climate, 26, 4773-4789, https://doi.org/10.1175/jcli-d-12-00298.1, 2013.

Feng, J., Wang, L., Chen, W., Fong, S. K., and Leong, K. C.: Different impacts of two types of Pacific Ocean warming on Southeast Asian rainfall during boreal winter, J. Geophys. Res.-Atmos., 115, D24122, https://doi.org/10.1029/2010jd014761, 2010.

Feng, J., Chen, W., Tam, C. Y., and Zhou, W.: Different impacts of El Niño and El Niño Modoki on China rainfall in the decaying phases, Int. J. Climatol., 31, 2091-2101, https://doi.org/10.1002/joc.2217, 2011.

Fraedrich, K., Jiang, J., Gerstengarbe, F. W., and Werner, P. C.: Multiscale detection of abrupt climate changes: application to River Nile flood levels, Int. J. Climatol., 17, 1301-1315, https://doi.org/10.1002/(SICI)10970088(199710)17:12<1301::AID-JOC196>3.0.CO;2-W, 1997.

Gerlitz, L., Vorogushyn, S., Apel, H., Gafurov, A., UngerShayesteh, K., and Merz, B.: A statistically based seasonal precipitation forecast model with automatic predictor selection and its application to central and south Asia, Hydrol. Earth Syst. Sci., 20, 4605-4623, https://doi.org/10.5194/hess-20-4605-2016, 2016.

Huang, B., Banzon, V. F., Freeman, E., Lawrimore, J., Liu, W., Peterson, T. C., Smith, T. M., Thorne, P. W., Woodruff, S. D., and Zhang, H.-M.: Extended Reconstructed Sea Surface Temperature (ERSST), Version 4, available at: https://data.nodc.noaa. gov/cgi-bin/iso?id=gov.noaa.ncdc:C00884 (last access: September 2017), 2015.

Huang, R., Chen, W., Yang, B., and Zhang, R.: Recent advances in studies of the interaction between the East Asian winter and summer monsoons and ENSO cycle, Adv. Atmos. Sci., 21, 407424, https://doi.org/10.1007/BF02915568, 2004.

Japan Agency for Marine Science and Technology: ENSO Modoki index Dataset: http://www.jamstec.go.jp/frsgc/research/d1/iod/ DATA/emi.monthly.txt, last access: August 2017.

Jiang, P., Gautam, M. R., Zhu, J., and Yu, Z.: How well do the GCMs/RCMs capture the multi-scale temporal variability of precipitation in the Southwestern United States?, J. Hydrol., 479, 75-85, https://doi.org/10.1016/j.jhydrol.2012.11.041, 2013.

Jiang, P., Yu, Z., Gautam, M. R., Yuan, F., and Acharya, K.: Changes of storm properties in the United States: Observations and multimodel ensemble projections, Global Planet. Change, 142, 41-52, https://doi.org/10.1016/j.gloplacha.2016.05.001, 2016.

Kalnay, E., Kanamitsu, M., Kistler, R., Collins, W., Deaven, D., Gandin, L., Iredell, M., Saha, S., White, G., and Woollen, J.: The NCEP/NCAR 40-year reanalysis project, B. Am. Meteorol. Soc., 77, 437-471, https://doi.org/10.1175/15200477(1996)077<0437:TNYRP>2.0.CO;2, 1996.

Kao, H.-Y. and Yu, J.-Y.: Contrasting eastern-Pacific and central-Pacific types of ENSO, J. Climate, 22, 615-632, https://doi.org/10.1175/2008JCLI2309.1, 2009.

Kim, H.-M., Webster, P. J., and Curry, J. A.: Impact of shifting patterns of Pacific Ocean warming on North Atlantic tropical cyclones, Science, 325, 77-80, https://doi.org/10.1126/science.1174062, 2009.

Larkin, N. K. and Harrison, D.: On the definition of El Niño and associated seasonal average US weather anomalies, Geophys. Res. Lett., 32, L13705, https://doi.org/10.1029/2005GL022738, 2005.

Li, Z., Cai, W., and Lin, X.: Dynamics of changing impacts of tropical Indo-Pacific variability on Indian and Australian rainfall, Sci. Rep., 6, 31767, https://doi.org/10.1038/srep31767, 2016.

Liu, X., Yuan, H., and Guan, Z.: Effects of ENSO on the relationship between IOD and summer rainfall in China, J. Trop. Meteorol., 15, 59-62, 2009.

$\mathrm{Lu}, \mathrm{R} .:$ Interannual variation of North China rainfall in rainy season and SSTs in the equatorial eastern Pacific, Sci. Bull., 50, 20692073, 2005.

Marteau, R., Sultan, B., Moron, V., Alhassane, A., Baron, C., and Traoré, S. B.: The onset of the rainy season and farmers' sowing strategy for pearl millet cultivation in Southwest Niger, Agric. Forest Meteorol., 151, 1356-1369, https://doi.org/10.1016/j.agrformet.2011.05.018, 2011.

$\mathrm{Niu}, \mathrm{N}$. and $\mathrm{Li}$, J.: Interannual variability of autumn precipitation over South China and its relation to atmospheric circulation and SST anomalies, Adv. Atmos. Sci., 25, 117-125, https://doi.org/10.1007/s00376-008-0117-2, 2008.

Omotosho, J. B., Balogun, A., and Ogunjobi, K.: Predicting monthly and seasonal rainfall, onset and cessation of the rainy season in West Africa using only surface data, Int. J. Climatol., 20, 865-880, https://doi.org/10.1002/10970088(20000630)20:8<865::AID-JOC505>3.0.CO;2-R, 2000. 
Onyutha, C. and Willems, P.: Spatial and temporal variability of rainfall in the Nile Basin, Hydrol. Earth Syst. Sci., 19, 22272246, https://doi.org/10.5194/hess-19-2227-2015, 2015.

Ouyang, R., Liu, W., Fu, G., Liu, C., Hu, L., and Wang, H.: Linkages between ENSO/PDO signals and precipitation, streamflow in China during the last 100 years, Hydrol. Earth Syst. Sci., 18, 3651-3661, https://doi.org/10.5194/hess-18-3651-2014, 2014.

Preethi, B., Sabin, T. P., Adedoyin, J. A., and Ashok, K.: Impacts of the ENSO Modoki and other tropical Indo-Pacific climate-drivers on African rainfall, Sci. Rep., 5, 16653, https://doi.org/10.1038/srep16653, 2015.

Ren, Z., Zou, F., Yu, Y., Wang, A., Zhang, Z., Fan, S., Zhang, Z., and Sun, C.: China Land Climate Dataset Version 3.0, available at: http://data.cma.cn/data/detail/dataCode/SURF_ CLI_CHN_MUL_DAY_V3.0.html (last access: August 2017), 2012.

Taschetto, A. S. and England, M. H.: El Niño Modoki impacts on Australian rainfall, J. Climate, 22, 3167-3174, https://doi.org/10.1175/2008jcli2589.1, 2009.

Tedeschi, R. G., Cavalcanti, I. F. A., and Grimm, A. M.: Influences of two types of ENSO on South American precipitation, Int. J. Climatol., 33, 1382-1400, https://doi.org/10.1002/joc.3519, 2013.

Trenberth, K. E.: The definition of El Niño, B. Am. Meteorol. Soc., 78, 2771-2777, https://doi.org/10.1175/15200477(1997)078<2771:TDOENO>2.0.CO;2, 1997.

Wang, B., Wu, R., and Fu, X.: Pacific-East Asian teleconnection: how does ENSO affect East Asian climate?, J. Climate, 13, 1517-1536, https://doi.org/10.1175/15200442(2000)013<1517:PEATHD>2.0.CO;2, 2000.

Wang, B., Zhang, Y., and Lu, M.: Definition of South China Sea monsoon onset and commencement of the East Asia summer monsoon, J. Climate, 17, 699-710, https://doi.org/10.1175/2932.1, 2004.

Wang, C. and Wang, X.: Classifying El Niño Modoki I and II by Different Impacts on Rainfall in Southern China and Typhoon Tracks, J. Climate, 26, 1322-1338, https://doi.org/10.1175/jclid-12-00107.1, 2013.

Wang, L., Chen, W., and Huang, R.: Interdecadal modulation of PDO on the impact of ENSO on the east Asian winter monsoon, Geophys. Res. Lett., 35, L20702, https://doi.org/10.1029/2008GL035287, 2008.

Wang, X., Li, C., and Zhou, W.: Interdecadal variation of the relationship between Indian rainfall and SSTA modes in the Indian Ocean, Int. J. Climatol., 26, 595-606, https://doi.org/10.1002/joc.1283, 2006.

Weng, H., Ashok, K., Behera, S. K., Rao, S. A., and Yamagata, T.: Impacts of recent El Niño Modoki on dry/wet conditions in the Pacific rim during boreal summer, Clim. Dynam., 29, 113-129, https://doi.org/10.1007/s00382-007-0234-0, 2007.

Weng, H., Wu, G., Liu, Y., Behera, S. K., and Yamagata, T.: Anomalous summer climate in China influenced by the tropical Indo-Pacific Oceans, Clim. Dynam., 36, 769-782, https://doi.org/10.1007/s00382-009-0658-9, 2011.

$\mathrm{Wu}, \mathrm{R} ., \mathrm{Hu}, \mathrm{Z} . \mathrm{Z}$. , and Kirtman, B. P.: Evolution of ENSO-related rainfall anomalies in East Asia, J. Climate, 16, 3742-3758, https://doi.org/10.1175/15200442(2003)016<3742:EOERAI>2.0.CO;2, 2003.
Wu, R., Yang, S., Wen, Z., Huang, G., and Hu, K.: Interdecadal change in the relationship of southern China summer rainfall with tropical Indo-Pacific SST, Theor. Appl. Climatol., 108, 119133, https://doi.org/10.1007/s00704-011-0519-4, 2012.

Xiao, M., Zhang, Q., and Singh, V. P.: Influences of ENSO, NAO, IOD and PDO on seasonal precipitation regimes in the Yangtze River basin, China, Int. J. Climatol., 35, 3556-3567, https://doi.org/10.1002/joc.4228, 2015.

$\mathrm{Xu}, \mathrm{K} ., \mathrm{Zhu}, \mathrm{C}$. , and Wang, W.: The cooperative impacts of the El Niño-Southern Oscillation and the Indian Ocean Dipole on the interannual variability of autumn rainfall in China, Int. J. Climatol., 36, 1987-1999, https://doi.org/10.1002/joc.4475, 2016.

Yuan, F., Berndtsson, R., Uvo, C. B., Zhang, L., and Jiang, P.: Summer precipitation prediction in the source region of the Yellow River using climate indices, Hydrol. Res., 47, 847-856, https://doi.org/10.2166/nh.2015.062, 2016a.

Yuan, F., Yasuda, H., Berndtsson, R., Bertacchi Uvo, C., Zhang, L., Hao, Z., and Wang, X.: Regional sea-surface temperatures explain spatial and temporal variation of summer precipitation in the source region of the Yellow River, Hydrol. Sci. J., 61, 13831394, https://doi.org/10.1080/02626667.2015.1035658, 2016b.

Zaroug, M. A. H., Giorgi, F., Coppola, E., Abdo, G. M., and Eltahir, E. A. B.: Simulating the connections of ENSO and the rainfall regime of East Africa and the upper Blue Nile region using a climate model of the Tropics, Hydrol. Earth Syst. Sci., 18, 43114323, https://doi.org/10.5194/hess-18-4311-2014, 2014.

Zhang, Q., Li, J., Singh, V. P., Xu, C. Y., and Deng, J.: Influence of ENSO on precipitation in the East River basin, South China, J. Geophys. Res.-Atmos., 118, 2207-2219, https://doi.org/10.1002/jgrd.50279, 2013.

Zhang, Q., Wang, Y., Singh, V. P., Gu, X., Kong, D., and Xiao, M.: Impacts of ENSO and ENSO Modoki+A regimes on seasonal precipitation variations and possible underlying causes in the Huai River basin, China, J. Hydrol., 533, 308-319, https://doi.org/10.1016/j.jhydrol.2015.12.003, 2016.

Zhang, R., Sumi, A., and Kimoto, M.: Impact of El Niño on the East Asian monsoon : A Diagnostic Study of the '86/87 and '91/92 Events, J. Meteorol. Soc. Jpn., 74, 49-62, https://doi.org/10.2151/jmsj1965.74.1_49, 1996.

Zhang, R., Sumi, A., and Kimoto, M.: A diagnostic study of the impact of El Niño on the precipitation in China, Adv. Atmos. Sci., 16, 229-241, https://doi.org/10.1007/BF02973084, 1999.

Zhang, R., Li, T., Wen, M., and Liu, L.: Role of intraseasonal oscillation in asymmetric impacts of El Niño and La Niña on the rainfall over southern China in boreal winter, Clim. Dynam., 45, 559-567, https://doi.org/10.1007/s00382-014-2207-4, 2014.

Zhang, W., Jin, F.-F., Li, J., and Ren, H.-L.: Contrasting impacts of two-type El Niño over the Western North Pacific during boreal autumn, J. Meteorol. Soc. Jpn., 89, 563-569, https://doi.org/10.2151/jmsj.2011-510, 2011.

Zhang, W., Jin, F.-F., Zhao, J.-X., Qi, L., and Ren, H.-L.: The possible influence of a nonconventional El Niño on the severe autumn drought of 2009 in Southwest China, J. Climate, 26, 8392-8405, https://doi.org/10.1175/jcli-d-12-00851.1, 2013.

Zhang, W., Jin, F. F., and Turner, A.: Increasing autumn drought over southern China associated with ENSO regime shift, Geophys. Res. Lett., 41, 4020-4026, https://doi.org/10.1002/2014GL060130, 2014. 
Zhang, W., Jin, F. F., Stuecker, M. F., Wittenberg, A. T., Timmermann, A., Ren, H. L., Kug, J. S., Cai, W., and Cane, M.: Unraveling El Niño's impact on the East Asian Monsoon and Yangtze River summer flooding, Geophys. Res. Lett., 43, 11375-11382, https://doi.org/10.1002/2016GL071190, 2016.
Zhou, W. and Chan, J. C.: ENSO and the South China Sea summer monsoon onset, Int. J. Climatol., 27, 157-167, https://doi.org/10.1002/joc.1380, 2007. 